\title{
The Inextricable Link Between Food and Linguistic Diversity: Wild Food Plants among Diverse Minorities in Northeast Georgia, Caucasus
}

\author{
Andrea Pieroni ${ }^{1,2}$, Renata Sóukand ${ }^{* 3}$, and Rainer W. Bussmann ${ }^{4}$ \\ ${ }^{1}$ University of Gastronomic Sciences, Pollenzo, Italy \\ ${ }^{2}$ Department of Medical Analysis, Tishk International University, Erbil, Kurdistan, Iraq \\ ${ }^{3}$ Department of Environmental Sciences, Informatics, and Statistics, Ca' Foscari University of Venice, \\ Venice, Italy \\ ${ }^{4}$ Ilia State University, Tbilisi, Georgia \\ *Corresponding author; e-mail: renata.soukand@unive.it; renata.herba@gmail.com
}

\begin{abstract}
The Inextricable Link Between Food and Linguistic Diversity: Wild Food Plants Among Diverse Minorities in Northeast Georgia, Caucasus. Divergences in the categorization and use of wild food plants among ethnic and linguistic groups living within the same environment are prototypical for the dual nature of biocultural diversity, which is generally richer on ecological and cultural edges. We interviewed 136 people from seven ethnolinguistic groups living in Georgia documenting the use of wild food plants. The results show the inextricable link between food and linguistic diversity; moreover, we observed a greater number of commonly used plants among Christian communities, as Muslim communities shared just one taxon widely used in all regions. Comparison with other Georgian regions and selected ethnic groups living in Azerbaijan showed lower use of wild food plants. Future investigations in the region should widen the ethnolinguistic research to include other aspects of ethnobiology and to dedicate more in-depth studies to understanding the underlying reasons for homogenization and plant-use erosion.
\end{abstract}

Key Words: Ethnobotany, Wild food plants, Georgia, linguistic minorities.

\section{Introduction}

In the past decade, ethnobiology has sparked growing interest in understanding the role of diverse social, economic, and political drivers affecting local plant knowledge systems, among them gender (Ayantunde et al. 2008; de Albuquerque et al. 2011; Karambiri et al. 2017; LuzuriagaQuichimbo et al. 2019; Montoya et al. 2012), age (Bortolotto et al. 2015; Brandt et al. 2013; Lunelli et al. 2016), socio-economic conditions (de Medeiros et al. 2012; Stryamets et al. 2015), religion (Bellia and Pieroni 2015; Pieroni et al. 2015), and geopolitical changes (Pieroni et al. 2017a; Sôukand and Pieroni 2016).

\footnotetext{
${ }^{1}$ Received 22 June 2020; accepted 25 November 2020; published online 4 January 2021
}

It has been estimated that by the year 2101, about half of the languages now known will disappear (Harrison 2008). While some languages "die out" naturally through the acculturation process, Skutnabb-Kangas and Phillipson (1996) defined the term "linguicide" as a process analogous to that of physical genocide, differentiating it from the natural death of a language through the presence of purposeful elements leading to its extermination. Plant names as well as other associated knowledge are related to the richness of the perception of one's environment and its use, being an expression of a very private sphere that may not be purposely targeted in the case of linguicide. Therefore, it is important to record both the plant names and uses of small linguistic groups in order to preserve the knowledge that will otherwise disappear with the language. Losing linguistic diversity also means losing biodiversity, as linguistic richness directly correlates to the high biodiversity of a region (Gorenflo 
et al. 2012; Harmon 1996). Moreover, divergences in the categorization and use of wild food plants among ethnic and linguistic groups living within the same environment (Panyadee et al. 2019; Pieroni and Sôkund 2019; Pieroni et al. 2017a, b, 2018, 2020; Quave and Pieroni 2015) are prototypical for the dual nature of biocultural diversity that is a complex socio-ecological adaptive system (Maffi and Woodley 2012). Biocultural diversity is generally richer on ecological and cultural edges (Turner et al. 2003) where different cultures and/ or ecosystems interact and are able to create new knowledge or adapt to new conditions.

While in Western Europe, traditional wild food plant gathering survives in its southern regions (Savo et al. 2019), industrialization and globalization have eroded traditional plant knowledge in most affluent countries (Menendez-Baceta et al. 2012). In Eastern Europe, centralization during the Communist era homogenized plant use diversity, and regional differences are relatively minor despite geographical and/or linguistic differences (Soukand and Pieroni 2016; Pieroni and Sóukand 2017, 2018), thus weakening the effect of the "edges."

The Caucasus also went through a complex process of Traditional Knowledge (TK) erosion, but, probably because of its peripheral location and mountain isolation, this effect was milder compared to other areas of the former Soviet Union, as recent fieldwork has shown a resilience of traditional foraging in currently independent countries like Georgia (Bussmann et al. 2016a, b, c, 2017, 2018; Łuczaj et al. 2017), Armenia (Hovsepyan et al. 2016; Pieroni et al. 2020), Azerbaijan (Pieroni and Sôukand 2019; Sôukand and Pieroni 2019), as well as the Republic of Dagestan (Kaliszewska and Kołodziejska-Degórska 2015), which is presently part of the Russian Federation. The richness of plant use is also demonstrated in a comprehensive review of the ethnobotany of the Caucasus (Bussmann 2017), yet it only outlines the currently most important taxa and does not specifically highlight the uses among linguistic minorities.

The aims of this study were a) to document local names and uses of wild food plants gathered among seven linguistic communities living in northeast Georgia, b) to compare the recorded plants and uses among the studied groups, and c) to compare the results with those obtained from neighboring Azerbaijan for Udis and Azeri. We expect to find greater differences in general plant use across borders, even within the same ethnic group, than within one region between different ethnic groups.

\section{Data and Methods}

\section{Study Area And Communities of the Field STUDY}

In spring of 2018, 14 villages inhabited by seven distinct linguistic groups were visited in northeast Georgia in the historical Kakheti region. The villages (Fig. 1) are located within an area approximately $100 \mathrm{~km}$ long and $50 \mathrm{~km}$ wide, at an elevation varying from 260 to 735 m.a.s.l. on the northern slopes of the Greater Caucasus Mountains. The environments around all the selected villages provide access to all listed plants, which grow within a short walking distance for all the groups studied. Table 1 provides the main characteristics of the visited linguistic groups as well as an overview of the selected sample interviewed. In all the minority linguistic groups, the people speak the language of the linguistic group, while Georgian is now the lingua franca for education and communication outside the village. However, formal education in the Soviet Union included an advanced level of Russian as a second language. Therefore, Russian was the lingua franca during the Soviet era among minorities. Still now, middle-aged and older men and women can speak Russian very well in the study area. We encountered only one or two people in each community (mainly very old women without formal education) who were not able to speak Russian well enough for productive conversation. While the Russian language was resisted by the Georgian majority during the Soviet period (Blauvelt 2013), this does not seem to be the case with minority groups.

The ethnic and linguistic diversity of the region requires some explanation. We refer to as Georgians those participants whose original native language is Georgian including all its dialects, and as Azeri those individuals who speak Turkic Azeri. Ossetians are a population group speaking Ossetic, an Eastern-Iranian/Avaric language (Harris 2002). This population migrated to the region from the Tskhinvali Region of Georgia (Sordi 2009). The Kists are originally from Chechnya, and the Bats (Tuva-Tush) come from Ingushetia and Chechnya. The Kists migrated to the region in the eighteenth century during the Shamil uprising (King 2009), while the Bats came to Georgian Tusheti much earlier and used Kakheti as a winter residence (Georgian Center for the Conservation of Wildlife (GCCW) 2007). Both groups speak languages belonging to the Nakh 


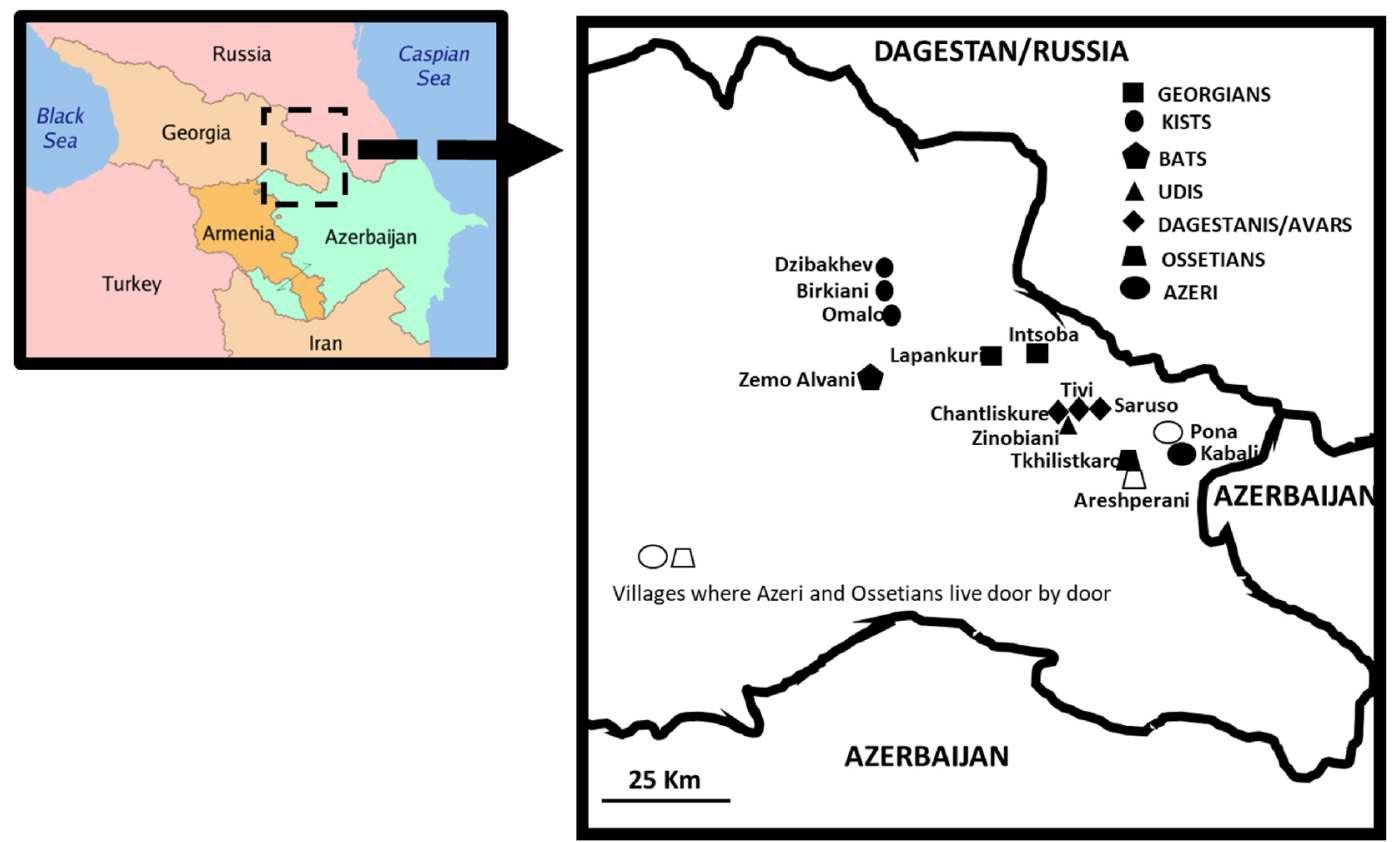

Fig. 1. Studied villages.

linguistic family - the Kists Chechen and the Bats originally Batsbur Mott (Harris 2002). The Kists living in the villages in which we worked are Muslims, while the Bats are Georgian Orthodox Christians. Similarly, the Udis and Avars both originated from an area currently located in the Republic of Dagestan. The Udi language belongs to the Lezgic language group (Harris 2002), whereas the Avar language belongs to a completely different language group (Hewitt 2004). While the Udi are Georgian Orthodox Christians, the Avars are Muslims.

We interviewed 136 people, either individually (about half of the interviews) or in groups of two or three. The oldest participant was born in 1928 and the youngest in 2001, with a mean age of 55 years. The interviewees were selected pseudo-randomly, by approaching people on the street and in their garden, or occasionally asking about more knowledgeable individuals in the village, targeting middleaged and older people, but including younger individuals if they happened to join the conversation. The semi-structured interviews were conducted in Russian by the second author, but in very few cases with elderly women and young individuals we asked someone from the same village fluent in Russian to help translate. While we had a bilingual (Georgian/ Russian) driver at our disposal in case a Georgian translation was needed, we never really required his assistance, apart from one interview in a Georgian village. Interviews (usually in the person's garden or on the street) lasted from 15 to $45 \mathrm{~min}$ and were followed, if possible, by a field walk with the interviewee. We asked the interviewees to list and show gathered and consumed wild food plants according to the following categories: 1 ) vegetables (cooked, fried, or fermented), 2) plants used for preparing dolma or sarma, 3) wild fruits and other wild plants used in sweet preserves and/or liquors, 4) wild plants used for herbal teas drunk in the food context without any medicinal purpose, and 5) wild plants used as snacks. As a rule, we avoided naming plants ourselves, so all questions were derived from the abovementioned general categories of plant use (e.g., What vegetables do you collect from the wild?). We recorded unusual uses of cultivated plants (like the cooking of young shoots of potato Solanum tuberosum L., a use earlier recorded in the high mountains of Georgia (Bussmann et al. 2016a) as well as those that were found both cultivated and wild (like the leaves of mulberry Morus sp. for making dolma). We also recorded local plant names and details on gathering and preparation. The Code of Ethics of the International Society of Ethnobiology (ISE (International Society of Ethnobiology) 


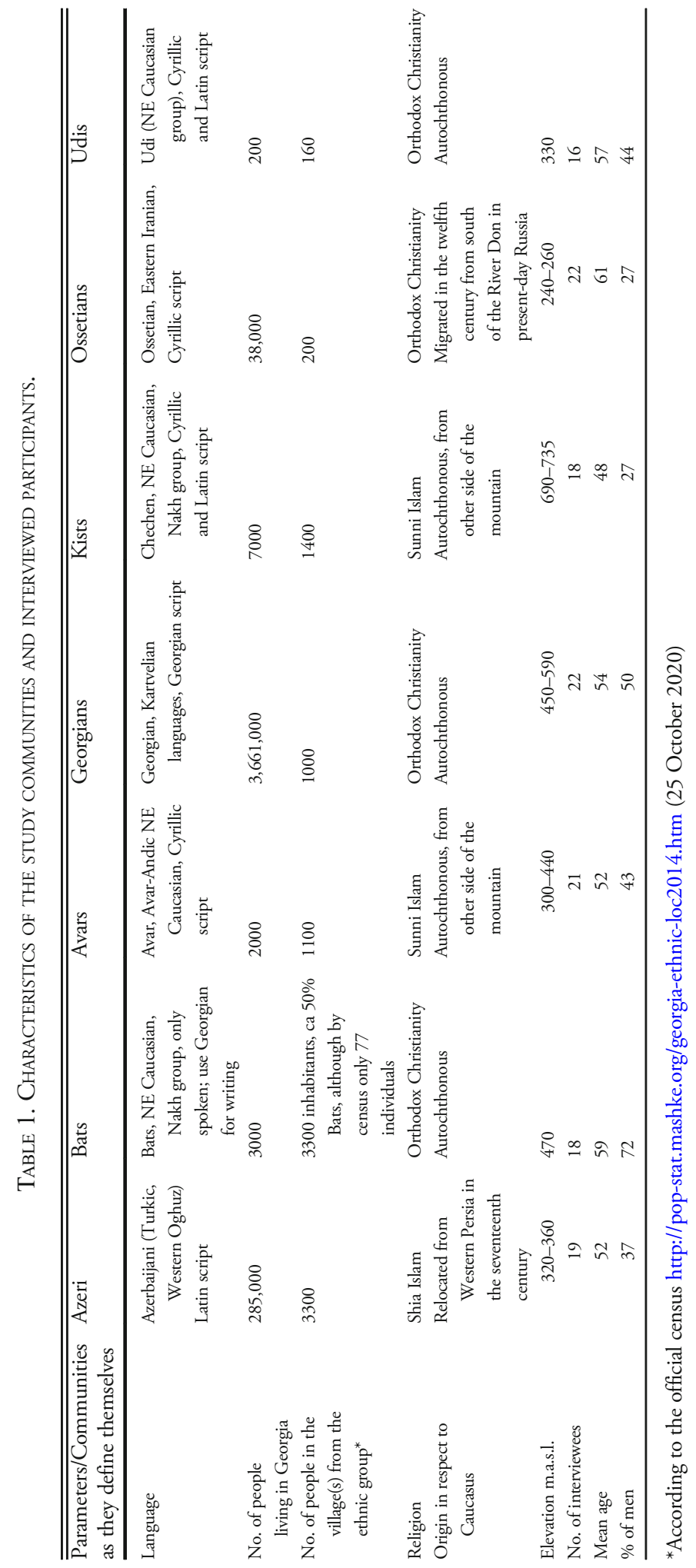


2006) was rigorously followed and oral informed consent was obtained prior to interviews. Only three people refused to participate due to the lack of time.

The nomenclature used here follows The Plant List database ( 2013) and the Flora Europaea (Tutin et al. 1964), and family assignments are consistent with the Angiosperm Phylogeny Group (APG) IV (Stevens 2017). Plants were identified via the Key to Plants of the Caucasus (Grossheim 1949), which uses slightly different nomenclature. If a plant specimen was not available, the taxon was identified based on a full description of the plant and its habitat as well as the local/Georgian/Russian name given by the interviewees. When the name in Russian or Georgian was provided on request, it was not considered the local one. When interviewees did not differentiate taxa at the species level, e.g., refer to different species of a genus with the same name, it was identified at the genus level, even if we collected plant samples for different representatives of the genus (for example, Rumex, Allium, and Mentha). In a few cases we were not able to identify the taxon and therefore those are presented as unidentified in Table 2 . The collected voucher specimens are deposited at the Herbarium of the Department of Environmental Sciences, Informatics, and Statistics of $\mathrm{Ca}^{\prime}$ Foscari University of Venice, Italy (UVV), in collaboration with the National Herbarium of Georgia, Tbilisi (NBGG), bearing herbarium numbers UVV.EB.GR01-34. One voucher was deposited with number UVV.EB.GRD01.

\section{DATA ANALYSIS}

All local plant names were transliterated using ISO 1984 for Romanization of the Georgian alphabet for Georgian and Azerbaijani for Azeri, while for the remaining languages names were reported in the Latin alphabet from the perspective of an English speaker. Data were transcribed from field notebooks and classified according to taxa and emic use categories. In a few rare cases we also recorded the local plant names even though the plant was only mentioned in conversation (as used by others) but not used in that specific community.

Use Instances (UI- the emic category of use of a taxon) were employed to evaluate the foodethnobotanical distance between the studied linguistic groups. We compared currently used taxa recorded using proportional Venn diagrams, visualizing the results with software developed by BioTuring Inc. located in San Diego, California,
USA [www.bioturing.com]. For both taxa and UIs, Jaccard Similarity Indices (JI) were calculated following the methodology of González-Tejero et al. (2008): $\mathrm{JI}=(\mathrm{C} /(\mathrm{A}+\mathrm{B}-\mathrm{C})) \times 100$, where $\mathrm{A}$ represents the number of taxa/UI in sample $A, B$ is the number of taxa/UI in sample $B$, and $C$ is the number of taxa/ UI common to A and B. If the result is close to 100 , the groups are very similar, whereas if there are few similarities, the index will be close to 0 .

For comparison and calculation of JI, some species were considered as one taxon (Malva, Mentha, Morus), whereas for Allium, all thin-leaved taxa with white flowers were combined under Allium spp., and $A$. victorialis $\mathrm{L}$. and $A$. atroviolaceum Boiss, which we were able to accurately identify were treated as separate taxa. Diverse taxa of Rumex were attributed to two groups: acidic (referred to as Rumex acetosa L.) and non-acidic (referred to as Rumex patientia L.).

When considering the most common taxa for the communities, the threshold was set at 20\%: if the taxon was mentioned by at least $20 \%$ of interviewees in a specific ethnic group, it was considered a commonly used taxon.

We compared our results with current and historical uses of wild plants in Georgia and also among the two ethnic groups for which we have carried out a comparable study in Azerbaijan (Pieroni and Soukand 2019). The study in Azerbaijan was conducted three weeks before the current study with a sample of 20 Azerbaijani, half of whom were internal refugees. That study was conducted by the first and second authors and used exactly the same methodological approach to the subject.

\section{Results and Discussion}

\section{Commonalties and Differences in Plants AND THEIR USES}

We recorded the food use of 46 plant species, two taxa identified at the genus level, and two taxa identified at the family level, from 24 plant families as well as two unidentified folk taxa (Table 2). The most represented families were Polygonaceae (5 species), Lamiaceae, and Apiaceae (4 species), as well as Amaryllidaceae, Asteraceae, and Malvaceae (3 species).

The largest number of taxa (19) were used for making traditional Georgian pkhali / mkhali (a dish based on raw minced vegetables and pureed walnuts, or simply boiled herbs, normally served with 


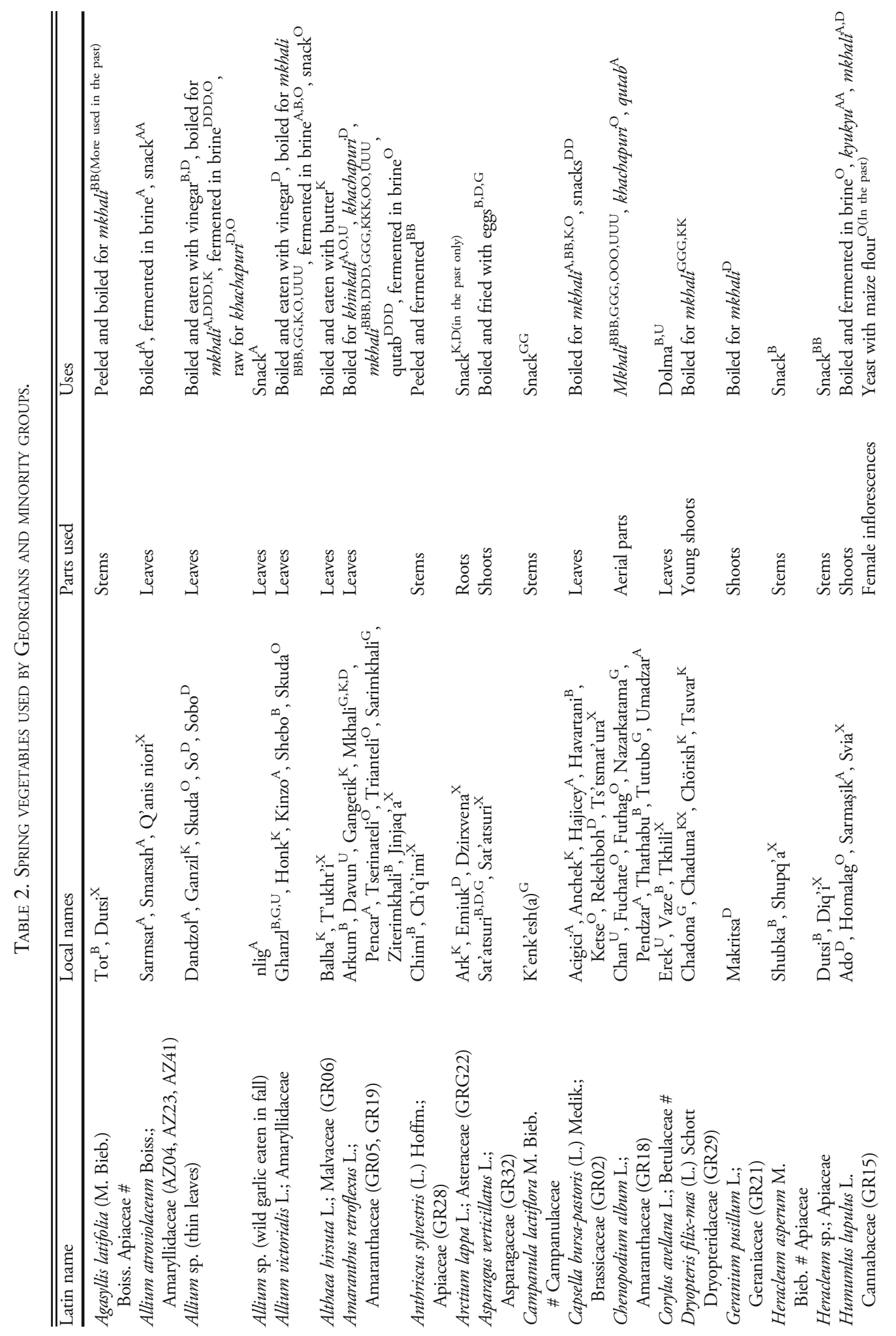




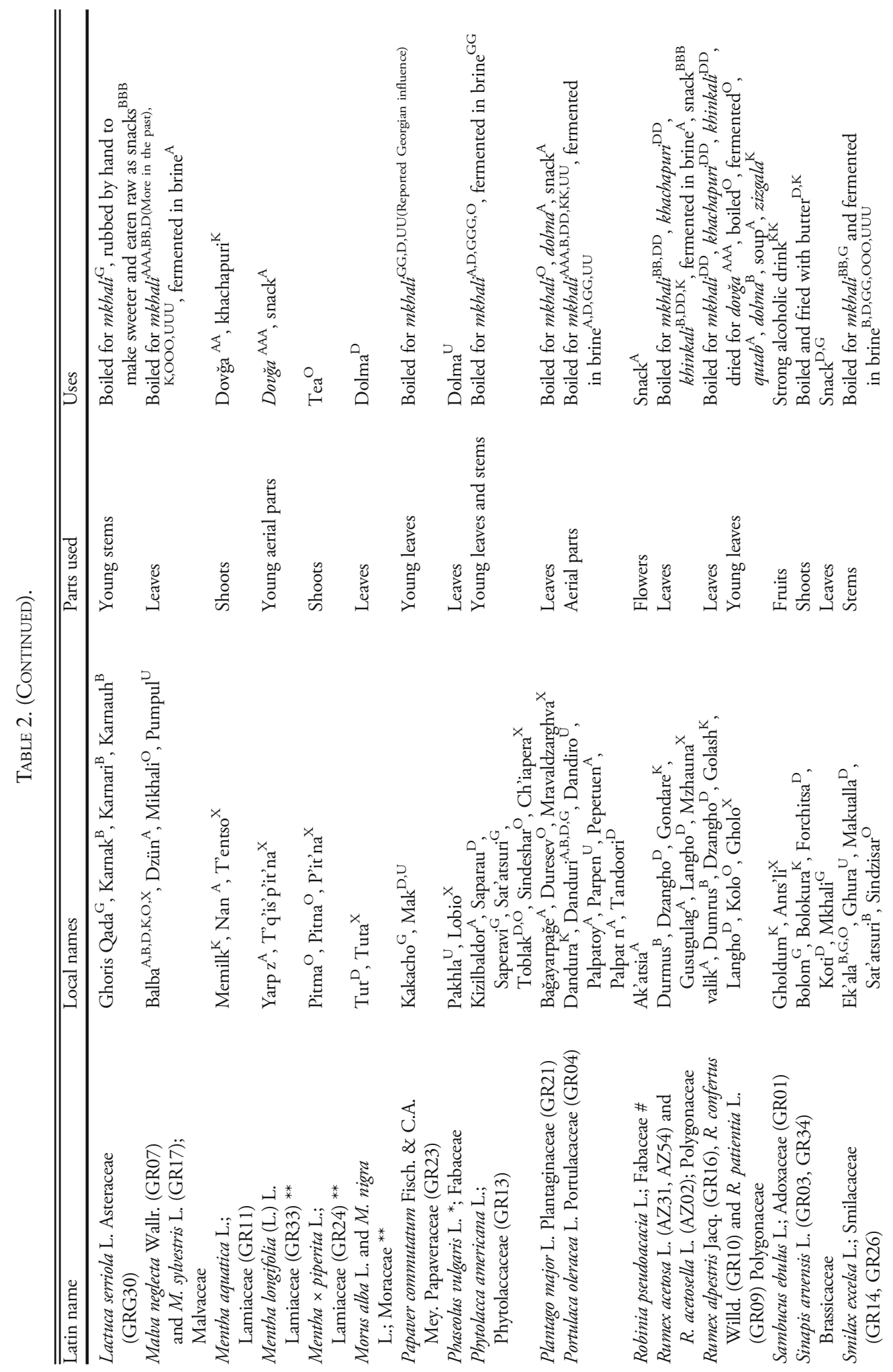




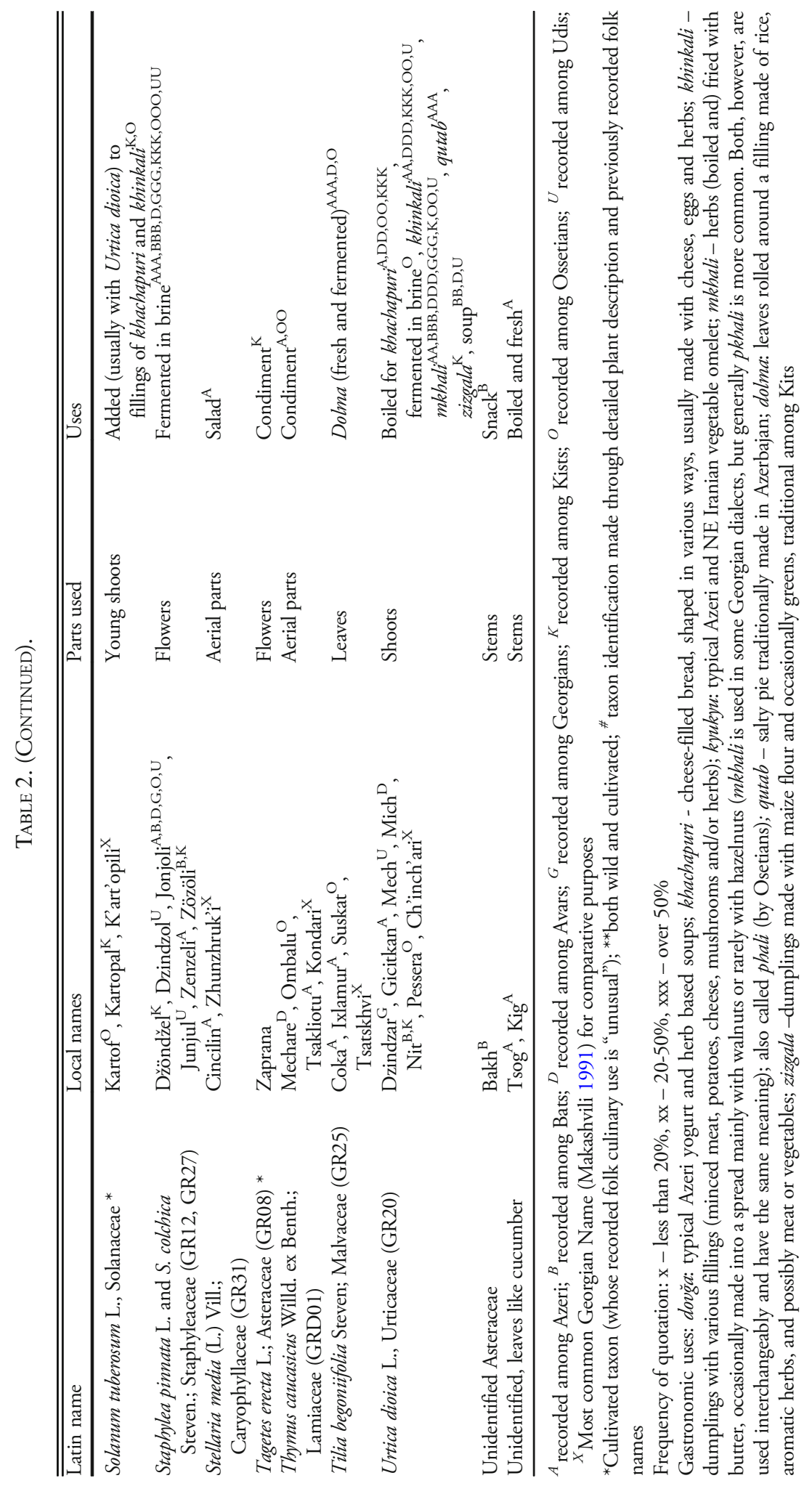




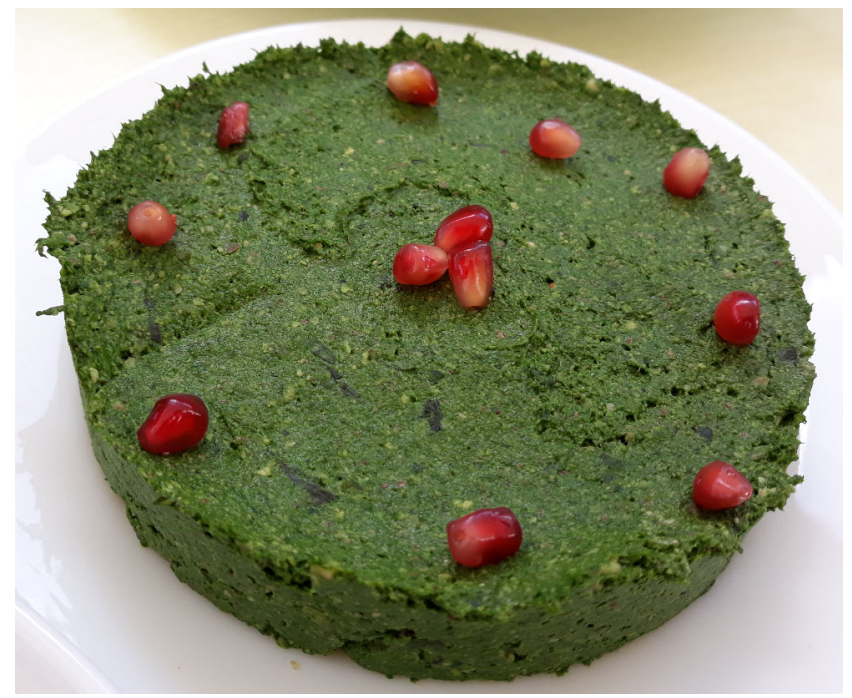

Fig. 2. Georgian pkhali.

pomegranate seeds, see Fig. 2), which are either briefly blanched (14) or raw (5). This underlines the importance of wild foods as an important source of greens, especially in the spring (the common term for the preparation is mndvris pkhali-spring phkali). Of the plants used, 11 were used by at least $20 \%$ of people in at least one community, the most popular being Amaranthus retroflexus L., Urtica dioica L., Chenopodium album L., Allium victorialis, and Portulaca oleracea L. Twelve plants were fermented in brine, yet only three of them were fermented by more than three to four participants in at least one community. The most popular of these was Staphylea pinnata L./ S. colchica Steven (Fig. 3). Of the 10 taxa that were snacked on raw, four were used by more than $20 \%$ of people in one community and one single taxon (Sinapis arvensis L.) was snacked on in two communities, yet mentioned only once in each. In addition, there were three taxa, which we were not able to identify, used as a snack by one community. Of the five taxa used for making dolma, only the leaves of Tilia begoniifolia Steven were used by more than three to four people. The addition of wild herbs into khachapuri(cheese-filled bread) was mentioned mainly among the Avars (three taxa), except for Urtica dioica, which was used in four communities. Another five taxa were used in the fillings for khinkali (traditional dumplings), the most popular of these being Urtica dioica.

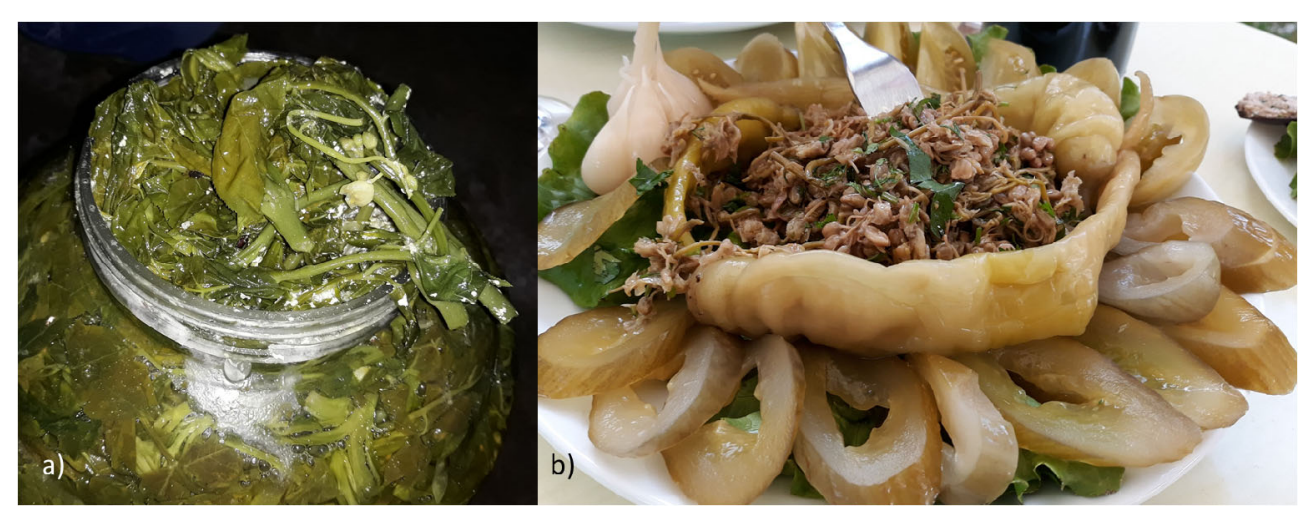

Fig. 3. Lactofermented jonjoli, Staphylea pinnata, in a (a) Kist village and (b) Georgian restaurant. 

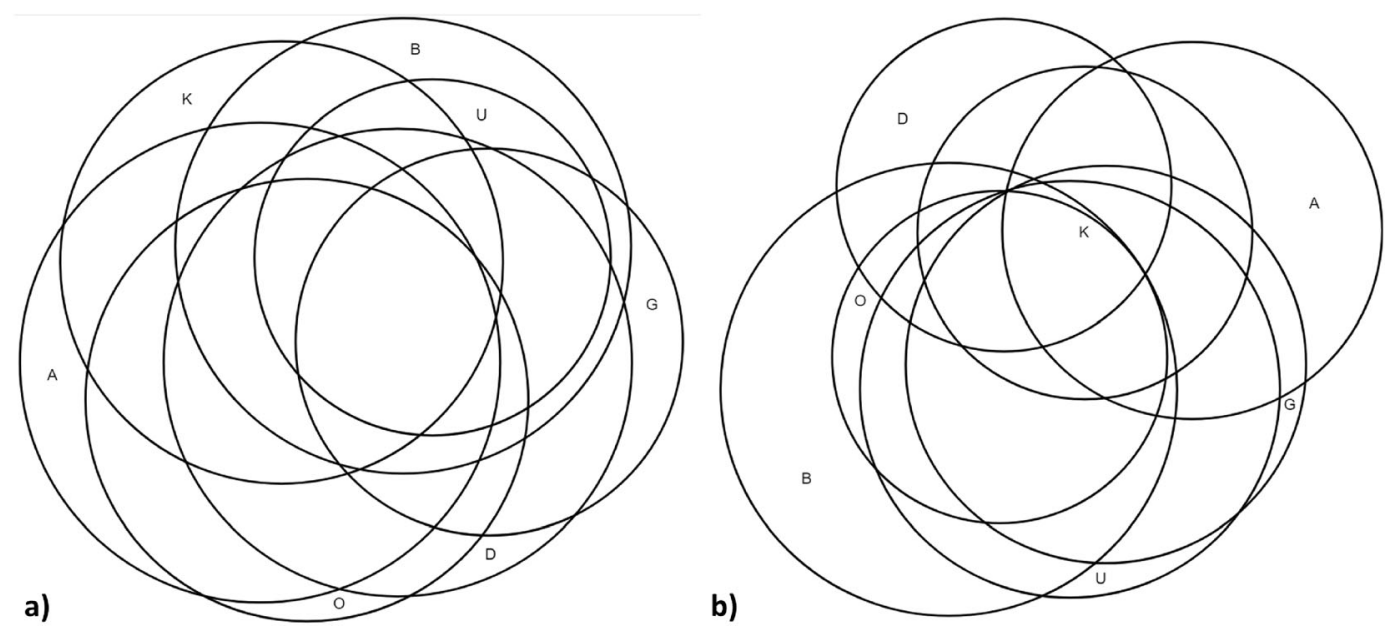

Fig.4. Best possible fit Venn diagram showing (a) the overlap of all used taxa and (b) the taxa used by at least $20 \%$ of community members. For abbreviations see Table 2.

In this regard, the Avars stood out by utilizing the greatest number of taxa (three), as did the Kists, who have a similar traditional dish called zizgala (dumplings made with maize flour) for which they utilized three taxa, although mentioned by fewer people. Notable is the infrequent, yet current consumption of boiled young shoots of Solanum tuberosum, which were usually mixed with Urtica dioica for filling khachapuri and khinkali, among Ossetian and Kist communities. The Azeri community stands out for using three taxa as ingredients of dovğa (a traditional Azeri yogurt soup).

The visual representation of wild food ethnobotanical distances in all used taxa (Fig. 4a) allows for little differentiation between the groups. However, if we select just the most often mentioned taxa, we can see a clearer distinction between the communities based on their religion (Fig. 4b), setting Christian communities (Bats, Georgians, Ossetians, and
Udis) slightly apart from Muslim communities (Azeri, Avars, and Kists). Calculated overlaps among all the taxa used by the groups (Table 3 ) also does not follow such a pattern, as for the majority of the communities the overlap is more or less the same, around $35 \%$. An overlap greater than $60 \%$ is found among the plants used by Azeri and Ossetians who live in mixed villages, while the overlap between Azeri and Avars was 52\% and between Udis and Georgians 50\% (the first pair shares the Islamic faith, while the others are Christian). The lowest values of JI for taxa were recorded in comparisons with the Udi community, being 25\% with Azeri and $26 \%$ with Kists and Ossetians.

The use of taxa in emic food preparations (expressed in UIs) was more diverse, creating on average around $20 \%$ overlap. Here, the extremes were between Azeri and Georgians (9\%) and again Udis and Georgians (35\%) and Udis and Bats (36\%), all of which are Orthodox Christian.

TABLE 3. JACCARd INDEXes For tAXa (LOWER LEFT CORNER) AND UIS (UPPER RIGHT CORNER). EXTREMES ARE HIGHLIGHTED IN BOLD.

\begin{tabular}{llllllll}
\hline \hline Gr taxa / Gr UI & $\mathrm{A}$ & $\mathrm{B}$ & $\mathrm{D}$ & $\mathrm{G}$ & $\mathrm{K}$ & $\mathrm{O}$ & $\mathrm{U}$ \\
\hline $\mathrm{A}$ & $\mathrm{X}$ & 15 & 23.08 & $\mathbf{9 . 0 9}$ & 17.78 & 26.09 & 17.5 \\
$\mathrm{~B}$ & 37.04 & $\mathrm{X}$ & 25 & 25.81 & 22.22 & 22.5 & $\mathbf{3 5 . 7 1}$ \\
$\mathrm{D}$ & $\mathbf{5 2}$ & 48 & $\mathrm{X}$ & 26.36 & 17.78 & 20.83 & 27.03 \\
$\mathrm{G}$ & $\mathbf{2 3 . 0 8}$ & 40.91 & 45.45 & $\mathrm{X}$ & 19.35 & 20 & $\mathbf{3 4 . 7 8}$ \\
$\mathrm{K}$ & 42.31 & 38.46 & 42.31 & 29.17 & $\mathrm{X}$ & 20.51 & 24.14 \\
$\mathrm{O}$ & $\mathbf{6 0 . 8 7}$ & 38.46 & 48 & 29.17 & 38.46 & $\mathrm{X}$ & 28.13 \\
$\mathrm{U}$ & $\mathbf{2 5}$ & 45 & 36.36 & $\mathbf{5 0}$ & $\mathbf{2 6 . 0 9}$ & $\mathbf{2 6 . 0 9}$ & $\mathrm{X}$ \\
\hline
\end{tabular}




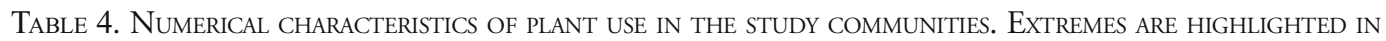
BOLD.

\begin{tabular}{llllllll}
\hline \hline Parameters/communities & $\mathrm{A}$ & $\mathrm{B}$ & $\mathrm{D}$ & $\mathrm{G}$ & $\mathrm{K}$ & $\mathrm{O}$ & $\mathrm{U}$ \\
\hline Taxa used & $\mathbf{2 0}$ & 18 & 19 & $\mathbf{1 3}$ & 18 & 18 & $\mathbf{1 1}$ \\
Taxa used by more than 20\% of interviewees & 9 & $\mathbf{1 3}$ & 7 & 10 & $\mathbf{6}$ & 8 & 10 \\
Taxa not shared with others & $\mathbf{4}$ & $\mathbf{4}$ & 2 & $\mathbf{0}$ & 2 & 1 & 1 \\
UIs & $\mathbf{3 2}$ & 23 & $\mathbf{3 2}$ & $\mathbf{1 6}$ & 21 & 26 & $\mathbf{1 5}$ \\
UIs named by at least 50\% of interviewees & 7 & 7 & $\mathbf{8}$ & 7 & $\mathbf{4}$ & $\mathbf{4}$ & 6 \\
\hline
\end{tabular}

The numerical characteristics of plant use (Table 4) do not single out any of the communities nor allow them to be easily grouped. Five communities mentioned quite a similar number of plants (from 18 to 20), while two groups, Georgians and Udis, mentioned 13 and 11 taxa, respectively. Two communities stand out for the number of taxa used exclusively by them (Azeri and Bats). The largest number of UIs (32), and thus the most diverse use, was recorded among Azeri and Avars. Also, the number of UIs was low among Georgians and Udis, both of which are autochthonous to the Caucasus.

Mapping of the distribution of use of the most important wild food taxa (named by at least $20 \%$ of people in a community) shows that there was only one taxon (Urtica dioica) commonly used by all the study communities (Fig. 5). Two more taxa were shared by six communities (Staphylea pinnata-all groups excluding the Avars, and Amaranthus retroflexus - all groups apart from the Azeri). Two groups of four communities each shared the use of one or more taxa. Of these, Smilax excelsa L., Chenopodium album, and Allium victorialis were notably shared exclusively among Orthodox Christian communities (Bats, Georgians, Ossetians, and Udis). The use of Portulaca oleracea was shared by Avars and Kists (Muslims) as well as Udis and Georgians (Christians), but there are no known descriptors that can be applied to all those communities simultaneously.

We can discern Udis and Georgians as the communities most similar in used plants as well as UIs. At the same time, the closeness of Azeri and Ossetians as well as Azeri and Avars are expressed in used plants, but not in dishes prepared from those plants.

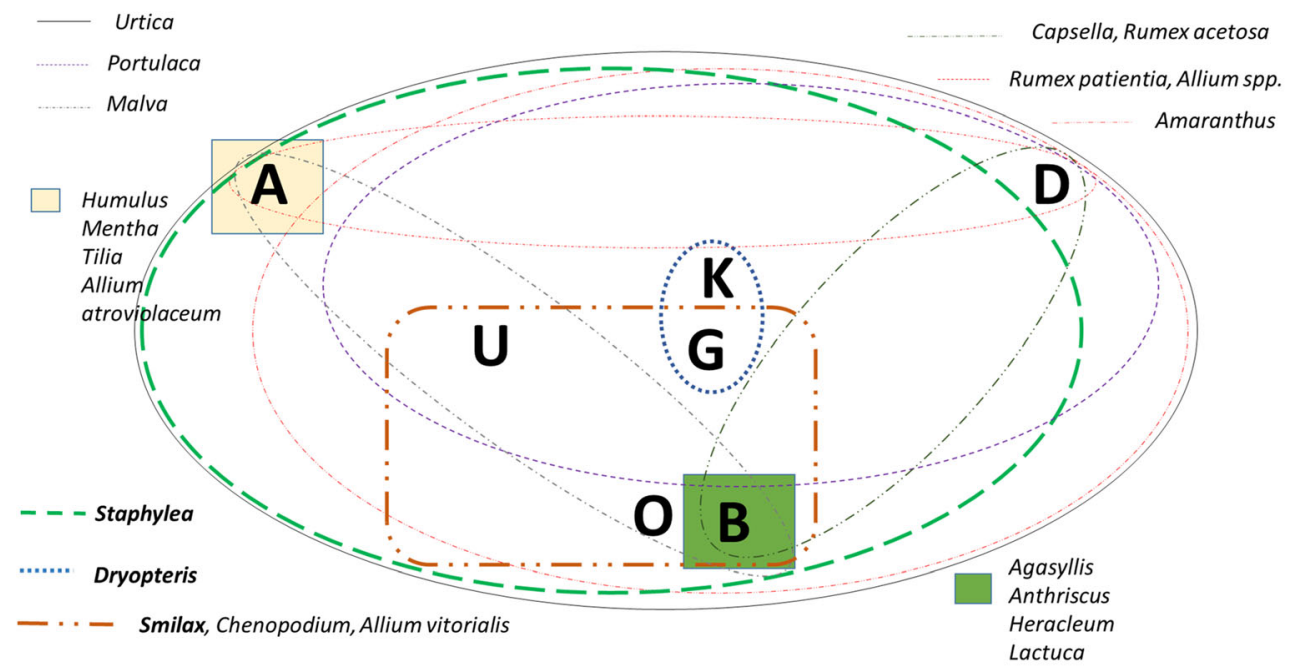

Fig. 5. Distribution of the most commonly used taxa (named by at least $20 \%$ of the people in a community) between the study communities. The highlighted taxa are further addressed in the discussion. Communities with the highest number of taxa not shared with other groups are in color. 


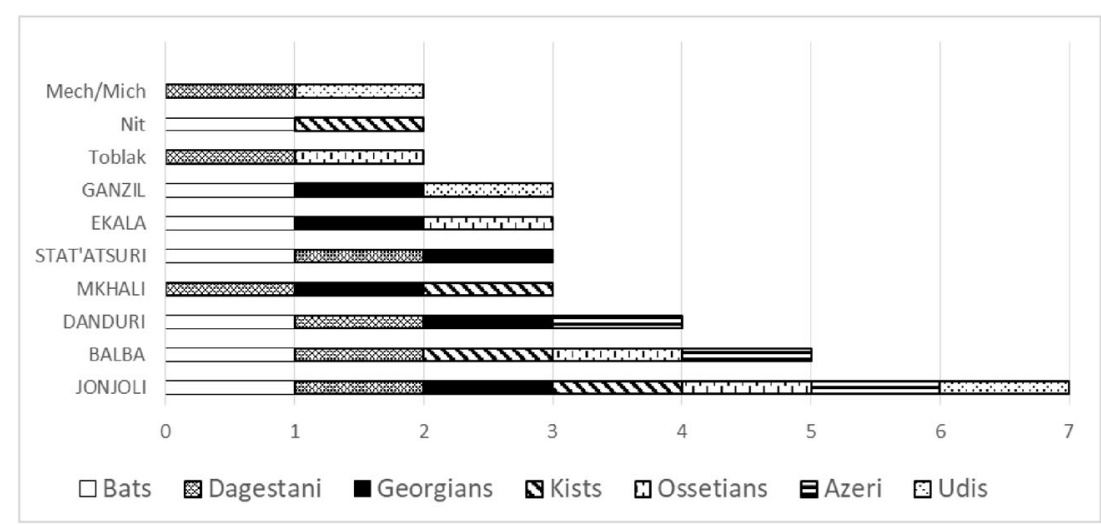

Fig. 6. Plant names shared by at least two groups. Plant names in CAPS are also used in standard Georgian.

\section{Linguistic Acculturation in Naming Plants IN THE ConteXT Of THEIR Use}

The influence of the Georgian language on the current naming of plants is clearly visible in seven names present in at least two communities (Fig. 6). The most influenced group (which uses six of the seven names) were the Bats, who use Georgian for written communication. However, surprisingly, the second greatest overlap was found for five taxa used by Avars, who do not share either religion or script. Kists, Ossetians, and Azeri borrowed Georgian names for three taxa, for which the Azeri also have names in their own language that are used in parallel (except for Staphylea). The plants and their emic use categories show that the uses are shared as well. Staphylea spp., bearing a name (jonjoli) widespread among all communities, was used in exactly the same way by all of them, as also widely done in other parts of Georgia (Batsatsashvili et al. 2017b).

As not all communities used all the plants, we cannot equally evaluate the possible presence of names commonly used in standard Georgian, yet we see Georgian influence in other names as well. For example, the Georgian name p'itna used for Mentha $\mathrm{x}$ piperita L. was also used among Ossetians, and Bats referred to Heracleum spp. as dutsi, which is also the common name across most of Georgia, while some Georgians call it ditse. The Georgians in the villages we visited did not use Balba (Malva sp.), yet the name is widespread among Georgians (Batsatsashvili et al. 2017a) and it is also known among "Azerized" Tsakhurs and Akhwaks in Azerbaijan (Sôukand and Pieroni 2019).

Balba was also one of four under-differentiated folk taxon names attributed to Malva and Althea (the latter among Kists). Of the other names, the most common were sat'atsuri (used for Asparagus verticillatus L. by Bats, Avars, and Georgians; Phytolacca americana L. by Georgians; and Smilax excelsa by Bats) and mkhali (like the widespread dish and used to refer to Sinapis arvensis by Georgians; Malva sp. by Avars; and Amaranthus retroflexus by Georgians, Kists, and Avars). Both Amaranthus retroflexus and Phytolacca americana, native to the American continent, have been introduced into the region relatively recently and have acquired the names of plants already in use for autochthonous wild food plants; such unambiguous naming could be, however, due to the ad hoc use of more common plant names by individual interviewees.

The influence of the Russian language is relatively limited and found mainly among Avars where Geranium pusillum L. was called makritsa and Papaver was called mak. Also, the Udi referred to Papaver as mak, although they reported a Georgian influence in its collecting, which may signify that at some point, Russian has been an important language of cultural exchange for Udis. This is also supported by the fact that Udis had only two plant names in common with Georgians (jonjoli and ghanzli).

It is also important to note that some plants still had different names despite common uses. The only extensively used plant, Urtica dioica, had only one name in common between two communities (Avars and Udis). It was followed by Chenopodium album, which was extensively used in the same way (mkhali) by four communities (Bats, Georgians, Ossetians, and Udis), yet had different names in all six languages in which it was named. An interesting case was that of Rumex spp., as non- 
acidicRumex had both diverse names and diverse uses in five communities, while acidic Rumex had some overlap in uses (for khinkali and mkhali) but had different names in four communities. Capsella bursa-pastoris (L.) Medik. was used mainly for making mkhali (by Azeri, Bats, Kists, and Ossetians) and referred to by different names in five communities. Two other taxa (Thymus caucasicus Willd. ex Benth. and Sinapis arvensis) were used by three communities and had diverse names. Thymus caucasicus was used only for seasoning by all three communities, while Sinapis arvensis was used in partially overlapping ways.

However, Azeri and Ossetians, who live in mixed villages and had the highest overlap in used plant species, did not have any plant names in common apart from the ones shared with Georgians.

\section{COMPARISON With Historical and CURRENT DATA ON GEORGIA}

Particularly interesting was the lack of plant use among Georgian participants in general, as well as the use of modified names by Georgians. Species such as Agasylis latifolia (M. Bieb.) Boiss, Allium atroviolaceum, Althea hirsuta L., Arctium lappa L., Capsella bursa-pastoris, and Rumex spp. are widely used for pkhali in many parts of Georgia (Bussmann et al. 2016b, 2017, 2018) by local Georgian inhabitants, but were not mentioned in this study. This might be due to the fact that pkhali use in general is much less common among Georgians in Kakheti because the short, relatively mild winters simply eliminate the need to use wild herbs as a source of vitamins. Corylus avellana L., widely used for making walnut spread by many Georgians all over the country, was also not mentioned by Georgian participants in this study.

Species whose stems are often pickled by the Georgian population in the mountainous regions of the country, such as Anthriscus sylvestris (L.) Hoffm., Heracleum asperum M. Bieb., and other Heracleum species, were not used by Georgians in the study area. This again can be seen as an expression of the fact that the Georgian population in Kakheti simply does not have to rely on these species as food, in contrast to the mountainous areas of the country where their use among Georgians is common; although the use of these species is more commonly associated with Armenian communities in Georgia (Bussmann et al. 2016c, 2017, 2018).

Similarly, all species of Mentha are used very frequently as tea in all parts of Georgia (Bussmann et al. 2016b, 2017), but were not mentioned by the Georgian participants in this study. Likewise, it is quite surprising that none of the Georgian participants reported the use of Morus alba or Sambucus ebulus L., at least for the production of local alcoholic beverages, which again is an indication that wild plant use is not popular among Georgians in Kakheti, the main wine and Chacha (similar to grappa) producing region.

Another indication of the lack of knowledge of wild plants and their uses among Georgians is the lack of knowledge of common Georgian names of important food plants, and their simple inclusion in generalized names for food preparations. For example, Amaranthus retroflexus is widely known as jinjaq'a in Georgian but was simply included in mkhali (the main form of preparation). Urtica dioica was abbreviated as dzindzar in contrast to the widely used common Georgian name ch'inch'ari (Bussmann et al. 2016b).

Interestingly, both Asparagus verticillatus and the non-nativePhytolacca americana were classified as sat'atsuri by the Georgians participating in this study. The second species was also called saperavi, which in fact is the official name of the most important red grape of the region, most likely in reference to the dark red berries of the species.

\section{Comparison with Azerbaijan}

Udis from the village of Zinobiani shared only a few names with the Udis from Nic, Azerbaijan (Pieroni and Sóukand 2019): Erek for Corylus avellana and Mech for Urtica dioica. The one name (Davun) used for Amaranthus in Zinobiani and for Chenopodium in Nic probably represents an underdifferentiated folk taxon. The shared uses went beyond the shared names and were shared rather widely with several communities in Georgia but used very little or not at all by the Udis in Azerbaijan (such as Amaranthus retroflexus, Malva spp., and Staphylea spp.). At the same time, Chenopodium album, Smilax excelsa, and Portulaca oleracea, widely eaten in Georgia, were used in Azerbaijan only by Udis. However, despite the fact that in Zinobiani Urtica dioica was used quite rarely, Udis in Nic widely reported making Afar (an Udi name for mkhali) with it, as well as frying it with eggs, as is done by many other ethnic groups in Azerbaijan. The Udis of Nic also fry Asparagus verticillatus, make dolma from the leaves of Fagus orientalis Lipsky as do several other ethnic groups in Azerbaijan, and the Udis in Nic are the only ones who fry 

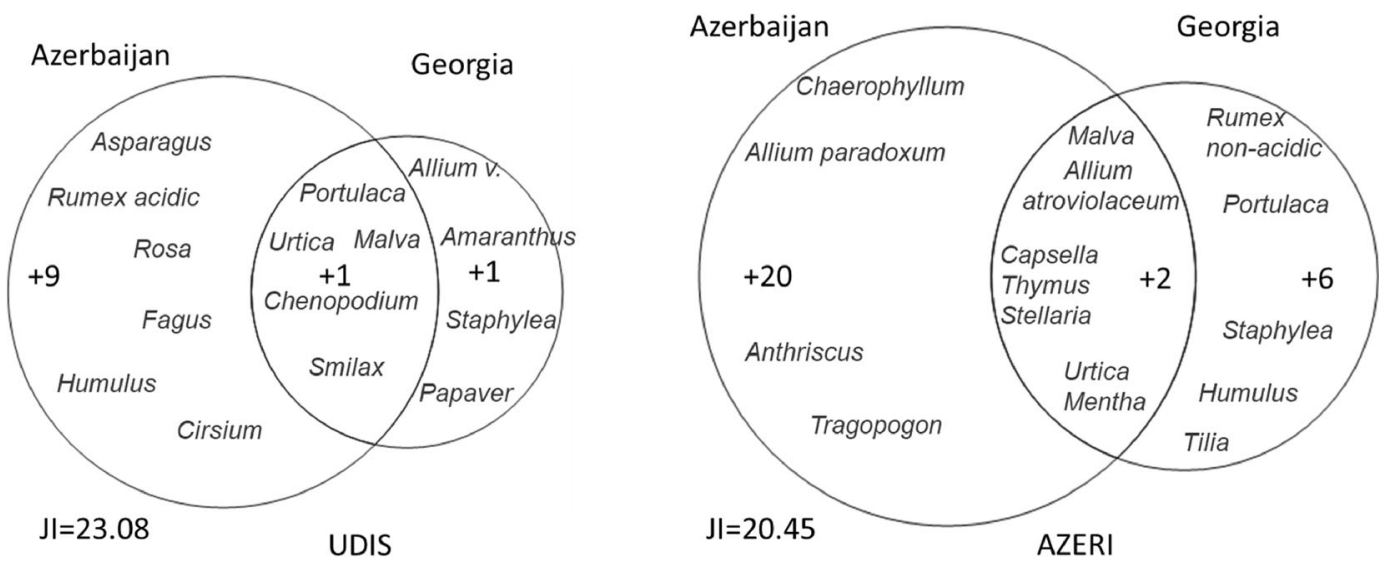

Fig. 7. Comparison of plant use among Azeri and Udis in Georgia and Azerbaijan.

young shoots of Humulus lupulus L. in Azerbaijan. This shows that most likely culinary contacts between the two villages were restricted and gathering from the wild has been influenced by neighboring communities.

Georgian Azeri, despite the fact that they came directly from Persia without stopping over in present-day Azerbaijan, as several interviewees recounted about their origin, also have some plant names in common with the Azeri in Azerbaijan (Pieroni and Soukand 2019). Overlaps were found mainly in terms of both names and uses: Yarp $z$ (Mentha longifolia [L.] L.) used for seasoning dovga, a traditional Azeri yogurt and herb-based soup, or Tsakliotu (Thymus caucasicus) used for food seasoning. Also, an overlap of names was found when the use did not overlap: Cincilin (Stellaria media) was used in Georgia solely for salad, but in Azerbaijan for a variety of foods. Nevertheless, Georgian Azeri shared the use of Staphylea spp. (not used in Azerbaijan) with several other ethnic groups in Georgia, as well as made kyukyu from the shoots of Humulus lupulus, which were used in Azerbaijan only by Udis and internal refugees, ethnic Kurds who retreated from the war in Nagorno-Karabakh in the 1990s. Georgian Azeri seemed to be the only group that had been using the national names of dishes (like kyukyu, dov a, qutab) at the same time or beyond the Georgian names.

Both the Udi and Azeri communities we interviewed in Azerbaijan used nearly twice as many taxa as their kin in Georgia (Fig. 7). This supports the idea that the small number of used wild food plants, especially those used by only a few people, may be related to the specific ecological conditions of the region and the greater availability of cultivated food.

\section{The "Synanthropic Fog" and UneXPeCted IMPORTANCE OF FORAGING IN THE FOREST}

A closer look at the most used plants allows for differentiating three layers representing different stages of the acquisition of knowledge on the use of plants. The most recent layer is represented by synanthropic weeds, which in archaeobotany are considered markers of Neolithic farming (Doebley et al. 2006; Delcourt 1987; Leonti 2012; Snir et al. 2015). We call this layer the "synanthropic fog," as it blurs possible interesting differences and has a homogenizing effect on foraging practices. To see the differences, we need to set aside the synanthropic genera of horticulture. However, if we compare the results of our current study with those from the Middle East (Pieroni et al. 2017b, 2018) we can see the interesting restricting role of this third layer. While there are around 15 commonly used synanthropic plants, we recorded only four that are widely used in the region (Urtica, Portulaca, Malva, and Chenopodium), which indicates that the practice of cultivating plants most likely did not originate in Georgia. Rather, the place of the origin of several crops is the Fertile Crescent, where nowadays synanthropic weeds are still widely consumed, especially among Assyrians (Pieroni et al. 2018).

The other two layers are related to the pre- and post-Neolithic periods and we can see them only after setting aside the synanthropic fog. The second 
layer calls attention to the autochthonous Bats, the only community that was still widely using taxa with clear connections to pastoralism (Agasylis, Anthrisus, and Heracleum), which is very unusual. Why are these communities still as pastoralist as they are? Being an autochthonous population, they should be very forest-oriented, as the area is well covered with forests. The reason for this discrepancy may be related to them originally living in isolation in very high settlements in the mountains, where they adopted pastoralism, until they were re-settled (due to landslides) in the middle of the nineteenth century. The widespread use of Heracleum and Anthriscus was also found among Bats and Azeri in Azerbaijan (Pieroni and Sôukand 2019), but not among the Georgian Azeri, who came from Persia and were not involved in pastoral activities, according to our interviewees. Coming down from the mountains recently, Bats retained an ecological attitude similar to that of the Avars and Azerbaijanbased Azeri.

The deepest layer is related to the pre-Neolithic use of plants and encompasses species found in the forest and associated with hunter-gatherer culture: Staphylea, Dryopteris, and Smilax, all widely used among a number of communities. The role of the forest and pre-Neolithic hunting and gathering practices among the studied communities in the Caucasus is evident, as Staphylea, Dryopteris, and Smilax are only rarely mentioned in the literature covering areas outside the region. Cooked shoots of Smilax species have also been recorded in diverse remote inland areas of Central Italy (Guarrera 2006), and the island of Sicily (Lentini and Venza 2007), as well as in Croatia (Dolina and Łuczaj 2014), Turkey (Akçin and Yalçin 2007; Dogan et al. 2004), and Nepal (Shrestha and Dhillion 2006), while the cooking and drying of Staphylea shoots for winter is widespread in central China (Kang et al. 2012a). For ferns, a comprehensive review of wild food plants (Turner et al. 2011) mentioned the eating of roots, not shoots, while there are records of boiling the shoots as vegetables in China (Kang et al. 2014; Liu et al. 2012). Dryopteris is used by Kists (who are autochthonous from Chechnya, on the other side of the mountains, and live in the highest villages we visited) and Georgians, who are autochthonous to the Caucasus and live at a slightly lower altitude. While Georgians have also brought Dryopteris into their gardens, it was not recorded as widely used in neighboring regions such as Armenia and Azerbaijan (Bussmann 2017).
We believe that the collection of forest ingredients, such as Staphylea, Dryopteris, and Smilax spp., is not directly linked to the gathering of wild greens growing in anthropogenic environments - which is prototypical of post-Neolithic farming settlements as well as the Mediterranean Diet (Pieroni and Cattero 2019) — nor to the pastoralist-driven activity of snacking on wild thistles (Mattalia et al. 2020). Forest gathering could represent the remains of past hunting/gathering activities, no matter how ancient, but certainly deriving from intense exposure of human communities to forest environments. Using woodland species for food represents only a small fraction of the possible foraging practices across the Georgian landscape. We did not, however, record the collection of acorns or the use of underground organs of woodland plants - two practices important for hunter-gatherers that are still partially alive in temperate forests in West and East Asia (Kang et al. 2012b; Ong et al. 2016; Pieroni et al. 2019).

\section{Conclusions}

Given the number of interviewed people and the different ethno-linguistic groups considered, the documented taxa were not very numerous, nor did they add much to the already documented species and knowledge of wild food plants. However, we observed a greater number of commonly used plants among Christian communities, while Muslim communities shared just one taxon widely used in all regions. After filtering out some "fog" created by the use of synanthropic plants, we could still see traces of pre-Neolithic foraging practices and postNeolithic pastoralist activities shared between some of the communities. The role of relocation as a negative factor in plant use could not be confirmed, as the two communities that exhibited a smaller number of plants and uses were autochthonous to the region, whereas the two non-autochthonous groups exhibited rather a large number of plants used as well as a variety of uses. The group that arrived most recently in the region (Azeri) has the highest number of used plants of all the groups, yet still much less diverse than the uses recorded in Azerbaijan. This can be explained by the fact that the practice of using wild food plants, which was brought to the region, has been lost less by the Azeri than by the other groups residing in the area for a longer period of time. What other factors have played a role in the low number of used taxa in 
the region in general needs further in-depth research. The use of Georgian plant names among minority ethnic groups was observed relatively often, and simultaneously the difference in naming and uses compared with earlier research conducted among related ethnic groups showed little overlap, demonstrating traceable acculturation and homogenization of plant use within this multilinguistic and multicultural setting. Future investigations in the region should widen the ethnolinguistic research to include other aspects of ethnobiology and to dedicate more in-depth studies to understanding the underlying reasons for homogenization and plant use erosion.

\section{Acknowledgments}

We are thankful to the study participants who shared with the authors their LEK. We would also like to thank the University of Gastronomic Sciences and $\mathrm{Ca}^{\prime}$ Foscari University of Venice for funding the field study. This research made use of the BioVinci visualization software, version 1.1.5, r20181005, developed by BioTuring Inc., San Diego, California, USA, www.bioturing.com.

\section{Funding}

Open access funding provided by Università $\mathrm{Ca}^{\prime}$ Foscari Venezia within the CRUI-CARE Agreement.

Open Access This article is licensed under a Creative Commons Attribution 4.0 International License, which permits use, sharing, adaptation, distribution and reproduction in any medium or format, as long as you give appropriate credit to the original author(s) and the source, provide a link to the Creative Commons licence, and indicate if changes were made. The images or other third party material in this article are included in the article's Creative Commons licence, unless indicated otherwise in a credit line to the material. If material is not included in the article's Creative Commons licence and your intended use is not permitted by statutory regulation or exceeds the permitted use, you will need to obtain permission directly from the copyright holder. To view a copy of this licence, visit http://creativecommons.org/licenses/by/4.0/.

\section{Literature Cited}

Akçin, T. B. Ö. Ö. E. and S. Yalçin. 2007. Nutrition contents of some wild edible plants in Central Black Sea Region of Turkey. International
Journal of Natural and Engineering Sciences 1: 11-13.

Ayantunde, A. A., M. Briejer, P. Hiernaux, H. M. J. Udo, and R. Tabo. 2008. Botanical knowledge and its differentiation by age, gender and ethnicity in Southwestern Niger. Human Ecology 36(6):881-889.

Batsatsashvili, K., N. Mehdiyeva, G. Fayvush, Z. Kikvidze, M. Khutsishvili, I. Maisaia, S. Sikharulidze, D. Tchelidze, V. Alizade, A. Aleksanyan, N. Y. Paniagua Zambrana, and R. W. Bussmann. 2017a. Malva neglecta Wallr. Malva sylvestris L. In: Ethnobotany of the Caucasus: European Ethnobotany, ed., R. Bussmann, 395-403. Cham, Switzerland: Springer.

Batsatsashvili, K., Z. Kikvidze, M. Khutsishvili, I. Maisaia, S. Sikharulidze, D. Tchelidze, N. Y. P. Zambrana, and R. W. Bussmann. 2017b. Staphylea colchica Steven. Staphylea pinnata L. Staphyleaceae. In: Ethnobotany of the Caucasus: European ethnobotany, ed., R. Bussmann, 673676. Cham, Switzerland: Springer.

Bellia, G. and A. Pieroni. 2015. Isolated, but transnational: The glocal nature of Waldensian ethnobotany, Western Alps, NW Italy. Journal of Ethnobiology and Ethnomedicine 11:37.

Blauvelt, T. K. 2013. Endurance of the Soviet imperial tongue: The Russian language in contemporary Georgia. Central Asian Survey 32(2): 189-209.

Bortolotto, I. M., M. C. de Mello Amorozo, G. G. Neto, J. Oldeland, and G. Alves DamascenoJunior. 2015. Knowledge and use of wild edible plants in rural communities along Paraguay River, Pantanal, Brazil. Journal of Ethnobiology and Ethnomedicine 11:46.

Brandt, R., S.-L. Mathez-Stiefel, S. Lachmuth, I. Hensen, and S. Rist. 2013. Knowledge and valuation of Andean agroforestry species: The role of sex, age, and migration among members of a rural community in Bolivia. Journal of Ethnobiology and Ethnomedicine 9:83.

Bussmann, R. W., ed. 2017. Ethnobotany of the Caucasus. Cham, Switzerland: Springer.

Bussmann, R. W., N. Y. Paniagua Zambrana, S. Sikharulidze, Z. Kikvidze, D. Kikodze, D. Tchelidze, M. Khutsishvili, K. Batsatsashvili, R. E. Hart, and A. Pieroni. 2016a. Your poison in my pie-The use of potato (Solanum tuberosum L.) leaves in Sakartvelo, Republic of Georgia, Caucasus, and Gollobordo, Eastern Albania. Economic Botany 70(4):431-437. 
Bussmann, R. W., N. Y. Paniagua Zambrana, S. Sikharulidze, Z. Kikvidze, D. Kikodze, D. Tchelidze, M. Khutsishvili, K. Batsatsashvili, and R. E. Hart. 2016b. A comparative ethnobotany of Khevsureti, Samtskhe-Javakheti, Tusheti, Svaneti, and Racha-Lechkhumi, Republic of Georgia (Sakartvelo), Caucasus. Journal of Ethnobiology and Ethnomedicine 12:43. 2016c. Medicinal and food plants of Svaneti and Lechkhumi, Sakartvelo (Republic of Georgia), Caucasus. Medicinal and Aromatic Plants 5:266.

Bussmann, R. W., N. Y. Paniagua Zambrana, S. Sikharulidze, Z. Kikvidze, D. Kikodze, D. Tchelidze, K. Batsatsashvili, and R. E. Hart. 2017. Ethnobotany of Samtskhe-Javakheti, Sakartvelo (Republic of Georgia), Caucasus. Acta Societatis Botanicorum Poloniae 86(2): 3517.

2018. Unequal brothers-Plant and fungal use in Guria and Racha, Sakartvelo (Republic of Georgia), Caucasus. Indian Journal of Traditional Knowledge 17:7-33.

de Albuquerque, U. P., G. T. Soldati, S. S. Sieber, M. A. Ramos, J. C. de Sá, and L. C. de Souza. 2011. The use of plants in the medical system of the Fulni-ô people (NE Brazil): A perspective on age and gender. Journal of Ethnopharmacology 133(2):866-873.

de Medeiros, P. M., T. C. da Silva, A. L. Santos de Almeida, and U. P. de Albuquerque. 2012. Socio-economic predictors of domestic wood use in an Atlantic forest area (north-east Brazil): A tool for directing conservation efforts. International Journal of Sustainable Development \& World Ecology 19(2):189-195.

Delcourt, H. R. 1987. The impact of prehistoric agriculture and land occupation on natural vegetation. Trends in Ecology \& Evolution 2(2):39-44.

Doebley, J. F., B. S. Gaut, and B. D. Smith. 2006. The molecular genetics of crop domestication. Cell 127(7):1309-1321.

Dogan, Y., S. Baslar, G. Ay, and H. H. Mert. 2004. The use of wild edible plants in western and central Anatolia (Turkey). Economic Botany 58(4):684-690.

Dolina, K. and Ł. Łuczaj. 2014. Wild food plants used on the Dubrovnik coast (south-eastern Croatia). Acta Societatis Botanicorum Poloniae 83(3):175-187.

Georgian Center for the Conservation of Wildlife (GCCW). 2007. Tusheti protected areas-Field guide. Tbilisi, Georgia: GCCW.
González-Tejero, M. R., M. Casares-Porcel, C. P. Sánchez-Rojas, J. M. Ramiro-Gutiérrez, J. Molero-Mesa, A. Pieroni, M. E. Giusti, E. Censorii, C. de Pasquale, A. Della, D. Paraskeva-Hadijchambi, A. Hadjichambis, Z. Houmani, M. El-Demerdash, M. El-Zayat, M. Hmamouchi, and S. ElJohrig. 2008. Medicinal plants in the Mediterranean area: Synthesis of the results of the project Rubia. Journal of Ethnopharmacology 116(2):341-357.

Gorenflo, L. J., S. Romaine, R. A. Mittermeier, and K. Walker-Painemilla. 2012. Co-occurrence of linguistic and biological diversity in biodiversity hotspots and high biodiversity wilderness areas. Proceedings of the National Academy of Science 109(21):8032-8037.

Grossheim, A. 1949. Opredelitel Rastenij Kavkaza. Moscow: Sovetskaja Nauka.

Guarrera, P. M. 2006. Usi e tradizioni della flora italiana. Medicina popolare ed etnobotanica. Rome: Aracne Editrice.

Harmon, D. 1996. Losing species, losing languages: Connections between biological and linguistic diversity. Southwest Journal of Linguistics 15: 89-108.

Harris, A. C. 2002. Endoclitics and the origins of Udi Morphosyntax. Oxford, United Kingdom: Oxford University Press.

Harrison, K. D. 2008. When languages die: The extinction of the world's languages and the erosion of human knowledge. Oxford, United Kingdom: Oxford University Press.

Hewitt, G. 2004. Introduction to the study of the languages of the Caucasus. Munich: Lincom Europa.

Hovsepyan, R., N. Stepanyan-Gandilyan, H. Melkumyan, and L. Harutyunyan. 2016. Food as a marker for economy and part of identity: Traditional vegetal food of Yezidis and Kurds in Armenia. Journal of Ethnic Foods 3(1):32-41.

ISE (International Society of Ethnobiology). 2006. International Society of Ethnobiology Code of Ethics (with 2008 additions). http://ethnobiology.net/code-of-ethics/ (21 May 2020).

Kaliszewska, I. and I. Kołodziejska-Degórska. 2015. The social context of wild leafy vegetables uses in Shiri, Daghestan. Journal of Ethnobiology and Ethnomedicine 11:63.

Kang, Y., Ł. Łuczaj, S. Ye, S. Zhang, and J. Kang. 2012a. Wild food plants and wild edible fungi of Heihe valley (Qinling Mountains, Shaanxi, central China): Herbophilia and indifference to 
fruits and mushrooms. Acta Societatis Botanicorum Poloniae 81(4):405-413.

Kang, Y., Ł. J. Łuczaj, and S. Ye. 2012b. The highly toxic Aconitum carmichaelii Debeaux as a root vegetable in the Qinling Mountains (Shaanxi, China). Genetic Resources and Crop Evolution 59(7): 1569-1575.

Kang, Y., Ł. Łuczaj, J. Kang, F. Wang, J. Hou, and Q. Guo. 2014. Wild food plants used by the Tibetans of Gongba Valley (Zhouqu county, Gansu, China). Journal of Ethnobiology and Ethnomedicine 10:20.

Karambiri, M., M. Elias, B. Vinceti, and A. Grosse. 2017. Exploring local knowledge and preferences for shea (Vitellaria paradoxa) ethnovarieties in Southwest Burkina Faso through a gender and ethnic lens. Forests, Trees and Livelihoods 26(1):13-28.

King, C. 2009. The ghosts of freedom: A history of the Caucasus. Oxford, United Kingdom: Oxford University Press.

Lentini, F. and F. Venza. 2007. Wild food plants of popular use in Sicily. Journal of Ethnobiology and Ethnomedicine 3:15.

Leonti, M. 2012. The co-evolutionary perspective of the food-medicine continuum and wild gathered and cultivated vegetables. Genetic Resources and Crop Evolution 59(7):1295-1302.

Liu, Y., W. Wujisguleng, and C. Long. 2012. Food uses of ferns in China: A review. Acta Societatis Botanicorum Poloniae 81(4):263-270.

Łuczaj, Ł., B. Tvalodze, and D. Zalkaliani. 2017. Comfrey and buttercup eaters: Wild vegetables of the Imereti Region in Western Georgia, Caucasus. Economic Botany 71(2):188-193.

Lunelli, N. P., M. A. Ramos, and C. J. F. de Oliveira, Jr. 2016. Do gender and age influence agroforestry farmers' knowledge of tree species uses in an area of the Atlantic Forest, Brazil? Acta Botanica Brasilica 30(4):667-682.

Luzuriaga-Quichimbo, C. X., M. H. del Barco, J. Blanco-Salas, C. E. Cerón-Martínez, and T. Ruiz-Téllez. 2019. Plant biodiversity knowledge varies by gender in sustainable Amazonian agricultural systems called chacras. Sustainability 11(15):4211.

Maffi, L. and E. Woodley. 2012. Biocultural diversity conservation: A global sourcebook. New York: Earthscan.

Makashvili A. 1991. Botanical dictionary, 3rd ed. Tbilisi: Metsniereba.

Mattalia, G., R. Sôukand, P. Corvo, and A. Pieroni. 2020. Wild food thistle gathering and pastoralism: An inextricable link in the biocultural landscape of Barbagia, Central Sardinia (Italy). Sustainability 12:5105.

Menendez-Baceta, G., L. Aceituno-Mata, J. Tardío, V. Reyes-García, and M. Pardo-de-Santayana. 2012. Wild edible plants traditionally gathered in Gorbeialdea (Biscay, Basque Country). Genetic Resources and Crop Evolution 59(7): 1329-1347.

Montoya, A., E. A. Torres-García, A. Kong, A. Estrada-Torres, and J. Caballero. 2012. Gender differences and regionalization of the cultural significance of wild mushrooms around $\mathrm{La}$ Malinche Volcano, Tlaxcala, México. Mycologia 104(4):826-834.

Ong, H. G., J.-M. Chung, H.-R. Jeong, Y.-D. Kim, K. Choi, C.-H. Shin, and Y.-M. Lee. 2016. Ethnobotany of the wild edible plants gathered in Ulleung Island, South Korea. Genetic Resources and Crop Evolution 63(3):409427.

Panyadee, P., H. Balslev, P. Wangpakapattanawong, and A. Inta. 2019. Medicinal plants in homegardens of four ethnic groups in Thailand. Journal of Ethnopharmacology 239:111927.

Pieroni, A. and V. Cattero. 2019. Wild vegetables do not lie: Comparative gastronomic ethnobotany and ethnolinguistics on the Greek traces of the Mediterranean Diet of southeastern Italy. Acta Botanica Brasilica 33(2):198-211.

Pieroni, A. and R. Sôukand. 2017. Are borders more important than geographical distance? The wild food ethnobotany of the Boykos and its overlap with that of the Bukovinian Hutsuls in Western Ukraine. Journal of Ethnobiology 37(2):326-346.

- 2018. Forest as stronghold of local ecological practice: Currently used wild food plants in Polesia, Northern Ukraine. Economic Botany 72(3):311-331.

. 2019. Ethnic and religious affiliations affect traditional wild plant foraging in Central Azerbaijan. Genetic Resources and Crop Evolution 66(7):1495-1513.

Pieroni, A., A. Nedelcheva, and Y. Dogan. 2015. Local knowledge of medicinal plants and wild food plants among Tatars and Romanians in Dobruja (South-East Romania). Genetic Resources and Crop Evolution 62(4):605-620.

Pieroni, A., R. Sóukand, C. L. Quave, A. Hajdari, and B. Mustafa. 2017a. Traditional food uses of wild plants among the Gorani of South Kosovo. Appetite 108:83-92. 
Pieroni, A., H. M. Ahmed, and H. Zahir. 2017b. The spring has arrived: Traditional wild vegetables gathered by Yarsanis (Ahl-e Haqq) and Sunni Muslims in Western Hawraman, SE Kurdistan (Iraq). Acta Societatis Botanicorum Poloniae 86:3519.

Pieroni, A., R. Sõukand, H. I. M. Amin, H. Zahir, and T. Kukk. 2018. Celebrating multireligious co-existence in Central Kurdistan: The bio-culturally diverse traditional gathering of wild vegetables among Yazidis, Assyrians, and Muslim Kurds. Human Ecology 46(2): 217-227.

Pieroni, A., H. Zahir, H. I. M. Amin, and R. Sóukand. 2019. Where tulips and crocuses are popular food snacks: Kurdish traditional foraging reveals traces of mobile pastoralism in Southern Iraqi Kurdistan. Journal of Ethnobiology and Ethnomedicine 15:59.

Pieroni, A., R. Hovsepyan, A. K. Manduzai, and R. Sóukand. 2020. Wild food plants traditionally gathered in central Armenia: Archaic ingredients or future sustainable foods. Environment, Development and Sustainability 20(8). https://doi. org/10.1007/s10668-020-00678-1. (16 November 2020).

Quave, C. L. and A. Pieroni. 2015. A reservoir of ethnobotanical knowledge informs resilient food security and health strategies in the Balkans. Nature Plants 1(2):14021.

Savo, V., F. Salomone, F. Bartoli, and G. Caneva. 2019. When the local cuisine still incorporates wild food plants: The unknown traditions of the Monti Picentini Regional Park (Southern Italy). Economic Botany 73:28-46.

Shrestha, P. M. and S. S. Dhillion. 2006. Diversity and traditional knowledge concerning wild food species in a locally managed forest in Nepal. Agroforestry Systems 66:55-63.

Skutnabb-Kangas, T. and R. Phillipson. 1996. Linguicide and linguicism. Kontaktlinguistik. Contact Linguistics. Linguistique de contact. Ein Internationales Handbuch zeitgenössiger Forschung. An International Handbook of
Contemporary Research. Manuel international des recherches contemporaines 1:667-675.

Snir, A., D. Nadel, I. Groman-Yaroslavski, Y. Melamed, M. Sternberg, O. Bar-Yosef, and E. Weiss. 2015. The origin of cultivation and proto-weeds, long before Neolithic farming. PLoS One 10(7):e0131422.

Sordi, G. 2009. Ossetians in Georgia in the wake of the 2008 War. European Centre for Minority Issues (ECMI) Working Paper \#45.

Sóukand, R. and A. Pieroni. 2016. The importance of a border: Medical, veterinary, and wild food ethnobotany of the Hutsuls living on the Romanian and Ukrainian sides of Bukovina. Journal of Ethnopharmacology 185:17-40.

___ 2019. Resilience in the mountains: Biocultural refugia of wild food in the Greater Caucasus Range, Azerbaijan. Biodiversity and Conservation 28(13):3529-3545.

Stevens, P. F. 2017. Angiosperm Phylogeny Website, version 14. http://www.mobot.org/ MOBOT/research/APweb (10 August 2019).

Stryamets, N., M. Elbakidze, M. Ceuterick, P. Angelstam, and R. Axelsson. 2015. From economic survival to recreation: Contemporary uses of wild food and medicine in rural Sweden, Ukraine and NW Russia. Journal of Ethnobiology and Ethnomedicine 11:53.

The Plant List. 2013. Available at: http://www. theplantlist.org/ (15 September 2019).

Turner, N. J., I. J. Davidson-Hunt, and M. O'Flaherty. 2003. Living on the edge: Ecological and cultural edges as sources of diversity for social—ecological resilience. Human Ecology 31(3):439-461.

Turner, N. J., Ł. J. Łuczaj, P. Migliorini, A. Pieroni, A. L. Dreon, L. E. Sacchetti, and M. G. Paoletti. 2011. Edible and tended wild plants, traditional ecological knowledge and agroecology. Critical Reviews in Plant Sciences 30(1-2):198-225.

Tutin, T., V. Heywood, N. Burges, D. Valentine, S. Walters, and D. Webb. 1964. Flora Europaea. Cambridge, United Kingdom: Cambridge University Press. 